\title{
KEBAHAGIAAN DALAM PANDANGAN THOMAS AQUINAS DAN HAMKA
}

\author{
Oleh:Rahmadon \\ rahmadonmadon96@gmail.com
}

\begin{abstract}
Abstrak : Bahagia dalam pandangan Thomas Aquinas yang hakiki adalah ketika manusia memandang Ilahi sebagai kebahagiaan yang tertinggi (Contemplation), manusia akan menemukan kebahagiaan sepenuhnya ketika manusia sudah beralih kepada dunia yang fana ini, yaitu ketika manusia sudah menghadap Ilahi atau sudah berada di alam Baqa. Menurut Hamka, bahagia terdiri dari dua macam, yaitu ukhrawi dan Duniawi. Kebahagiaan Ukhrawi merupakan kebahagiaan yang paling utama, karena kebahagian ini abadi. Seseorang yang berusaha mencapai kebahagiaan ukhrawi akan memiliki keoptimisan dan ketenangan dalam hidup. Ketika diakhirat pun, ia akan mendapat sebaik-baiknya balasan atas kebaikannya selama hidup di dunia. Sedangkan kebahagiaan duniawi, berupa akal dan budi, kesehatan tubuh dan jiwa serta harta yang cukup untuk memenuhi kebutuhan hidup dan berbagi dengan sesama sehingga manusia dapat beribadah dan bekerja dengan baik, kebahagiaan duniawi hanyalah suatu pelengkap karena manusia merupakan makhluk dualisme yang perlu dipenuhi kebutuhan rohani dan jasmaninya. Dalam hal Kebahagiaan Hamka dan Thomas memiliki suatu orientasi yang sama yaitu memandang sang Ilahi sebagai kebahagiaan yang Hakiki, juga tentu dalam hal kebahagiaan antara Hamka dan Thomas pun mengandung hal yang berbeda dalam konteks kebahagiaan manusia, karena bagaimana pun mereka merupakan Tokoh yang memiliki banyak perbedaan baik dari segi agamanya, periode kehidupannya dan sisi keilmuannya.
\end{abstract}

Kata Kunci :Kebahagiaan, Thomas Aquinas, Hamka 


\section{A. Pendahuluan}

Bahagia merupakan sesuatu hal yang lumrah dibicarakan dalam kehidupan manusia, karena semua manusia pasti memiliki orientasi dalam kehidupannya yaitu kebahagiaan, konteks bahagia yang diinginkan setiap manusia sangat beragam, dan tentunya nilai kebahagiaan setiap manusia itu memiliki suatu hal yang berbedabeda dalam hal kebahagian untuk dirinya. Dalam skripsi ini tentunya akan membahas mengenai kajian bahagia dalam diri manusia yang akan diberikan beberapa konsep kebahagian oleh para filsuf yang tersohor. Dalam Khazanah Filsafat Islam, banyak sekali tokoh-tokoh filsuf yang membicarakan mengenai kajian bahagia seperti halnya Ibn Maskawayh, al- Farābī dll.

Menurut Ibn Miskawayh untuk memperoleh kebahagiaan, manusia harus mencapai suatu derajat kemanusiaan yang tertinggi. Derajat ini dapat dicapai jika manusia mampu menyempurnakan kemampuan kognitif dan kemampuan praktis. Dengan kemampuan kognitif manusia cenderung pada berbagi ilmu pengetahuan sehingga wawasan dan kemampuan kerangka berpikirnya tepat dan akurat, sehingga ia bergerak maju mencapai pengetahuan tertinggi, yiatu pengetahuan Ilahi, pada kemampuan inilah segala keraguan menjadi hilang dan hati menjadi tentram. Sedangkan dengan kemampuan praktis, manusia akan mencapai kesempurnaan karakter yang harmonis dalam hidup, sehingga tercapai kebahagiaan yang menyeluruh bagi individu dan masyarakat. ${ }^{1}$

Tetapi di nusantara sendiri juga ada seorang tokoh yang terkenal dalam hal kajian mengenai kebahagiaan seseorang, yaitu Abdul Malik bin Abdul Karim Amrullah, atau lebih dikenal dengan nama Hamka. Dalam hal ini tokoh filsuf Nusantara yang bernama Hamka ini sangat menarik pemikirannya mengenai kebahagian manusia, Menurut Hamka kebahagiaan yang hakiki adalah kebahagiaan ukhrawi, karena kebahagiaan ukhrawi merupakan kebahagiaan yang tidak akan berubah dan lenyap di makan waktu. Manusia hidup di dunia hanya untuk singgah dan menyiapkan diri untuk menempuh alam akhirat. Dan di akhiratlah manusia akan mendapatkan kebahagiaan yang abadi, tidak seperti kebahagiaan duniawi yang mudah berubah dan hilang. ${ }^{2}$

Berbicara mengenai kebahagiaan, Allah Swt begitu Maha Pengasih dan Maha Penyayang, Allah begitu baik hingga memberikan bermacam kebahagiaan kepada manusia, yaitu kebahagiaan ukhrawi dan duniawi. Dan hal yang terpenting untuk dicapai manusia adalah suatu kebahagiaan yang hakiki yang berada di alam akhirat. 
Dalam pandangan ini, Hamka membagi kedalam kebahagiaan ukhrawi setelah kebahagiaan duniawi. Kebahagiaan ukhrawi merupakan puncak dari kebahagiaan, dan untuk memperolehnya dibutuhkan agama untuk mencapai kebahagiaan hakiki di akhirat. Tetapi di samping itu, manusia juga memerlukan kebahagiaan duniawi agar kebahagiaannya menjadi sempurna sebagai penunjang kebahagiaan akhirat. Kebahagiaan duniawi meliputi keutamaan-keutamaan dalam pribadi manusia seperti keutamaan otak dan budi, kesehatan tubuh dan jiwa, serta harta yang cukup. ${ }^{3}$

Menurut Aquinas, Kebahagiaan tidak terletak pada barang-barang ataupun makanan, pakaian dan lain sebagainya, itu termasuk kedalam kebahagiaan yang tidak sempurna, seperti yang dapat dimiliki dalam kehidupan ini, barang-barang eksterior diperlukan, bukan sebagai esensi dari kebahagiaan, tetapi sebagai alat untuk kebahagiaan. ${ }^{4}$

\section{B. Pengertian Kebahagiaan}

Sebelum membahas kebahagiaan lebih jauh saya terlebih dahulu akan membahas mengenai pengertian lahir batin.Pada tata bahasa Arab terdapat beberapa kata yang berakar pada kata $s a^{\prime} \bar{\alpha} d a h$, yaitu $s a^{\prime} \bar{\alpha} d a h$ atau sa'ida yang artinya beruntung, as'adu yang artinya membahagiakan, tas'ada yang artinya mengharapkan kebahagiaan dan istas'ada yang artinya menganggap sesuatu sebagai keberuntungan. Selanjutnya, masih dalam tata bahasa Arab juga disebutkan bahwa al-

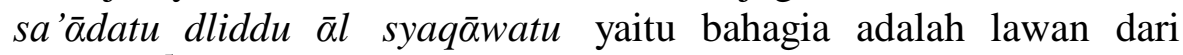
kesialan. ${ }^{5}$

Pada Ensiklopedia Islam,kata bahagi (sa' $\bar{\alpha} d a h)$ berarti kebahagiaan, keberuntungan, majur, tidak sial. Kebahagiaan secara etimologis berarti suatu keadaan senang, tentram, terlepas dari keadaan yang buruk. Kamus ilmu tasawuf, sa' $\bar{\alpha}$ dah berarti kedekatan dengan Allah Swt serta keluasan rahmat-Nya yang tidak terbatas. Dalam buku Pengantar Studi Islam dijelaskan bahwa kebahagiaan itu tidak sama dengan kesenangan (pleasure), karena kesenangan lebih dinisbatkan pada kesenangan belaka, namun kebahagiaan bisa hanya sekedar kesenangan fisik yang sementara, akan tetapi, juga bisa mencapai tingkat kesenangan yang transenden dan abadi. ${ }^{6}$

Dengan demikian, dalam pandangan para pakar kebahagiaan itu mempunyai tingkatan yang berbeda, hal ini karena berpandangan terhadap kebaikan yang mempunyai tingkatan yang berbeda, hal ini karena berpandangan karena kebaikan yang mempunyai tingkatan, dimana kebahagiaan berpadanan dengan kebaikan, dan kebaikan itu 
bertingkat- tingkat, begitu pula dengan kebahagiaan juga mempunyai tingkatan-tingkatan tertentu.

\section{Kebahagiaan dalam Filsafat Yunani}

Berbicara mengenai kebahagiaan dalam pandangan filsafat Yunani, tentunya tidak semua filsuf akan saya masukkan dalam pembahasan ini. Namun saya hanya menguraikan dua tokoh saja sebagai deskripsi dalam perspektif filsafat Yunani sebagai sebuah ulasan mengenai sebuah konsep tentang kebahagiaan. Karena menurut saya kedua tokoh ini sangat berpengaruh pemikirannya tentang kebahagiaan terhadap tokoh-tokoh berikutnya, dan bukan hanya filsuf Yunani saja bahkan filsuf Islam juga terpengaruh. Walaupun banyak pemikir lainnya yang mungkin begitu terkenal ataupun tersohor namanya, tetapi menurut penulis kedua tokoh ini sudah memberikan deskripsi yang baik untuk saya uraikan.

\section{Platon}

Platon lahir pada tahun 428/7SM dalam suatu keluarga terkemuka di Athena. Ayahnya bernama Ariston seorang bangsawan keturunan raja Kodrus, raja terakhir Athena yang hidup sekitar 1068 SM. Platon meninggal dunia di Athena pada tahun347 SM dalam usia 80 tahun. Plato berasal dari keluarga aristokrasi yang turun menurun memegang peranan penting dalam politik Athena. ${ }^{9}$ Sebuah keluarga bangsawan yang kaya raya, yang hidup ketika Yunani menjadi pusat kebudayaan terbesar selama empat abad. Generasi orang tua kakeknya sudah hidup selama setengah abad kebangkitan Athena menuju kebesaran dan kekuasaannya yang paling hebat, dan secara langsung keluarga Plato terlibat aktif dalam politik di kotanya. ${ }^{7}$

\section{Aristoteles}

Aristoteles (384 SM-322 SM), ia lahir di Stageria, Yunani Utara. Ayahnya bernama Machaon, ia adalah seorang dokter pribadi raja Macedonia Amyntas II. Dari kecil ia mendapatkan asuhan dari ayahnya sendiri. Ia mendapatkan pelajaran dalam hal teknik membedah, karena itu perhatiannya banyak bertumpah kepada ilmu-ilmu alam terutama ilmu biologi. ${ }^{8}$ Pada usia 18 tahun ia masuk Akademia di Athena dan sampai tahun 347 SM menjadi murid Plato, Aristoteles menjadi murid Plato kira- kira 20 tahun sampai Plato meninggal dunia. ${ }^{9}$ Sedangkan pada tahun 342 SM 
ia diangkat menjadi pendidik Iskandar Agung Muda dikerajaan Philipus di Makedonia. Tahun 335 SM.

Aristoteles kembali ke Athena dan mendirikan sekolah yang disebut lykaion atau Sekolah Peripatetik, yang sebenarnya sebagai pusat penelitian ilmiah. ${ }^{10}$ Tahun 323 SM merupakan tahun ketidakberuntungan bagi Aristoteles yaitu tepatnya sesudah meninggalnya Iskandar Agung dimana Aristoteles harus melarikan diri dari Athena dan pergi ke Kalkis di Euboe, karena Aristoteles difitnah menyebarkan Subverif dan Ateisme sampai meninggal dunia pada tahun 322 SM. Karya-karyanya cukup banyak tetapi yang berbicara etika yaitu, Ethica Nicomachea, Magna Moralia (karangan besar tentang moral), dan Ethica Eudemia. ${ }^{11}$

\section{Kebahagiaan dalam Filsafat Islam}

Setelah saya membahas kebahagiaan dalam filsafat Yunani, pada bagian ini, saya akan bahas kebahagiaan dalam pandangan filsafat Islam. sebagai deskripsi konsep pemikiran tentang suatu kebahagiaan, saya memasukkan dua tokoh filsuf muslim yang akan saya bahas, yaitu Ibn Miskawayh dan Al- Ghāzālī, karena menurut saya tokoh ini sangat menarik untuk dimasukkan dalam penulisan ini, walaupun banyak tokoh lain yang mungkin sangat tersohor dalam membahas mengenai kebahagiaan seperti Al-Farābī dan lain sebagainya, tapi penulis hanya mengutip dua tokoh ini untuk sebuah deskripsi terhadap pemikiran kebahagiaan ini.

\section{Ibn Miskawayh}

Ibn Miskawayh dilahirkan di desa Ray, masuk wilayah Iran. Menurut Margolioth, dia dilahirkan sekitar tahun 330 H. Atau beberapa tahun sebelumnya, sedangkan menurut Abdurrahman alBadawih, dia dilahirkan kira-kira tahun 320 . $\mathrm{H}$ atau sebelum tahun itu. Ibn Miskawayh berumur cukup panjang dan meninggal dunia di Isfahan pada 9 Shafar $421 \mathrm{H} / 16$ Februari $1030 \mathrm{M}^{12}$

Adapun perkembangan ilmu Ibn Miskawayh terutama sekali diperoleh dengan jalan banyak membaca buku, pertama disaat memperoleh kepercayaan menguasai perpustakaan Ibn Al-Amid, Mantri Rukn Al-Daulah, juga akhirnya memperoleh kepercayaan sebagai bendaharawan 'Adhud Al-Daulah. Menurut Ensiklopedia Islam di Indonesia, Ibn Miskawayh adalah seorang filosof Islam 
yang pertama kali membicarakan masalah akhlak dalam bukunya Tahzīb al-Akhlōk.

Ia menjelaskan masalah jiwa, penyakit jiwa dan cara mengobatinya, selain belajar filsafat, ia mempelajari sejarah terutama karya yang berjudul at-Thobāri Annals dari Abu Bakar Ahmad ibn Kamil al- Qodhi. Ilmu filsafat didapatkan dari Ibn al- Khammar, sedangkan filsafat Aristotelesdan ilmu kimia dipelajari bersama-sama dengan Abu al-Thoyyib al-Rozi, selain bidang ilmu filsafat ia juga dikenal sebagai tabib. ${ }^{13}$

\section{Al- Ghāzāli}

Al-Ghāzālī (1058 H./1111 M.), nama lengkapnya adalah Abu Hamid Muhammad bin Muhammad al- Tusi Al-Ghāzālī. Versi lain menyebutkan bahwa nama lengkap Imam Al- Ghāzālī dengan gelarnya adalah Syaikh al-Azāl al-Imān al-Zahīd, al- saīd alMawāfāq Hujjātul Islam. Zaīnul Syarāf mengatakan bahwa nama lengkap Imam al-Ghāzālī adalah al-Ummah bin Muhammad bin Muhammad al-Ghāzālī al-Tūs. Imam Al-Ghāzālī dilahirkan pada tahun 450 (1058) dibesarkan di kota Tus, sekarang dekat Masyhad, sebuah kota kecil di Khurasan yang sekarang adalah Iran. Imam Al-Ghāzālī lahir dari keluarga yang sederhana, ayahnya adalah seorang pengusaha yang memintal wol dan menjual ditokonya sendiri. ${ }^{14}$

Pada tanggal 14 Jumadil Akhir tahun 505 H, Imam Al-Ghāzālī meninggal dunia. Imam al-Ghāzālī adalah seorang ulama besar dan juga seorang penulis yang terkenal, karya- karya yang beliau hasilkan sangat banyak, sebagian besar peneliti menerangkan bahwa Imam $\bar{\alpha}$ l- Ghōzōli menulis hampir 100 buku yang meliputi berbagai pengetahuan, seperti ilmu kalam (Theologi Islam), Fiqih (Hukum Islam), Tasawuf, Filsafat, Akhlaq dan Otobiografi, karangannya itu ditulis dalam bentuk bahasa Arab dan Persia, sebagian pendapat lain mengatakan bahwa karagan AlGhazali mencapai kira-kira 70 buku, namun yang berkaitan dengan tema saya tentang kebahagiaan yang begitu terkenal yaitu kitab, Kimiy $\bar{\alpha} t u s ~ S a ' \bar{\alpha} d a h$, dan kitab Ihyō' Ulumuddīn, yang saya ketahui. 


\section{E. PEMIKIRAN KEBAHAGIAAN THOMAS AQUINAS}

\section{A. Biografi Thomas Aquinas}

\section{Riwayat Hidup Thomas Aquinas}

Menurut Bertrand Russell, ${ }^{15}$ Thomas Aquinas lahir dari keluarga bangsawan Aquinas (Aquino) di Rocca Secca, tidak jauh dari Napoli (Italia). Pada akhir tahun 1225 (atau awal 1226). Ibunya masih mempunyai hubungan keluarga dengan Kaisar Fredik II yang pada waktu itu berkuasa. Pada usia lima tahun (1230), dilihat ada suatu kesamaan di sana. Dalam hal ini saya menganalisis pemikir Islam diatas, bahwa, untuk memandang kebahagiaan di dunia jangan dijadikan suatu tempat untuk mengharapkan kebahagiaan yang hakiki.

Karena kebahagiaan yang hakiki adanya di alam akhirat dan manusia hanya dituntut untuk melakukan yang terbaik di dunia ini dengan melakukan segala apa yang menjadi tuntutan untuk mencapai suatu kebahagiaan yang hakiki. Sudah barang tentu bahwa kebahagiaan di dunia ini bersifat semu dan sementara dan akhiratlah kebahagiaan tertinggi itu diperoleh.

Thomas diserahkan oleh orang tuanya ke Biara Benediktin di Monte Cassino dengan harapan bahwa kelak ia memilih hidup membiara. Di sana Thomas menjalani pendidikan awalnya. Pada tahun 1239, Biara Benekditin tersebut dipaksa bubar, karena para rahib diusir oleh Kaisar Frederik II. Dalam usia 14 tahun, Thomas menjadi mahasiswa pada Universitas Napoli yang baru saja didirikan atas desakan dan pengaruh Kaisar Frederik II. Di kota itu ada biara Dominikin. Thomas sangat tertarik pada pola hidup mereka. Pada Tahun 1244, ia diterima masuk biara tersebut. Tetapi usaha Thomas tidak disetujui oleh segenap keluarganya, karena mereka menghendaki agar Thomas kembali ke Monte Cassino dan menjadi seorang rahib Benekditin.

\section{Latar Belakang Intelektualnya}

Thomas Aquinas Pada tahun1248-1252 setelah beberapa waktu ia berada di Paris, lalu Thomas pindah ke Koeln (Jerman). Ia menjadi murid Santo Albertus Agung. Dapat diperkirakan bahwa upaya Santo Albertus Agung untuk memanfaatkan filsafat Aristoteles dalam berteologi memberikan pengaruh awal bagi arah dan gaya berfikir Thomas Aquinas. Dan akhirnya nanti Thomas Aquinas terkenal sebagai teolog dan filsuf yang secara 
kreatif mampu menciptakan sintesis seluruh pemikiran Kristiani dengan memanfaatkan sistem dan konsep-konsep filsafat Aristoteles. Pada tahun 1252-1256, Thomas mengajar di Paris tanpa gelar sebagai magister atau master. Sebetulnya, ia sudah mendapatkan gelar tersebut, tetapi terhalang karena di Paris sedang terjadi konflik antara para biarawan dan penguasa sipil. Sebagai akibat dari konflik tersebut, para biarawan menolak untuk taat kepada universitas. Konsekuensinya, Thomas Aquinas dan Bonaventura tidak jadi menerima gelar magisternya. ${ }^{16}$

Hanya karena campur tangan dan perintah dari Paus di Roma, maka situasi keruh itu dapat dipulihkan, dan baru pada tahun 1257 Thomas baru mendapatkan gelar Magisternya. Pada tahun 1259, Thomas ditugaskan di Italia. Di sana ia mengajar teologi sambil membantu di lembaga pengadilan kepausan sampai tahun 1268. Ia antara lain mendampingi Paus Alexander IV di Anagni (1259-1261), Paus Urbanus IV di Orvieto (12611264) dan di Roma (1265-1267), dan Paus Urbanus IV. Thomas Aquinas bertemu untuk pertama kalinya dengan seorang penerjema ulung dari belgia bernama William dari Moerbeke. Untuk kepentingan pemeriksaan kasus-kasus teologis di pengadilan kepausan, William dari Moerbeke telah menerjemahkan karya-karya Aristoteles yang pada waktu itu dilarang. Terjemahan tersebut akhirnya menjadi sangat bermanfaat bagi Thomas Aquinas.

\section{Karya-Karya Thomas Aquinas}

Thomas Aquinas adalah seorang penulis yang tidak mengenal lelah. Ia mewariskan sejumlah besar karya tulis dalam bidang teologi dan filsafat. Tulisan-tuisannya membuktikan bahwa ia bukan sekedar seorang filsuf dan teolog, tetapi juga seorang religius. Dalam arti bahwa apa yang ditulisnya merupakan kebenaran- kebenaran yang diyakini dengan iman yang kokoh dalam kesatuan religi dengan Tuhan. Selain khotbahkhotbah dan komentarnya atas Kitab.

Suci serta liturgi Gereja, ia juga menulis komentar atas berbagai karya klasik. Komentar-komentar itu meliputi komentar atas Sentence karya Petrus Lombardus; dua, atas karya Boethius yang berjudul De Hebdomadibus dan Trinitate, dan komentar atas karya-karya utama dari Aristoteles, seperti 
Metaphysics, Nichomachean Ethics, De anima, Politics, De Caelo, dan Degeneratione et corruptione.

Dari sekian banyak karya otentik Thomas Aquinas, hanya beberapa yang dapat disebutkan. Pada tahap awal ketika mengajar di Paris, Thomas Aquinas menulis De principiis nature (1255), De ente et essentia (1256) dan De veritate (1256-1259). Ketika untuk pertama kalinya ia ditugaskan di Italia, ia menulis Summa Contra Gentelis, De Potentia, Contra errores Graecorum, De emptione et venditione dan De regimine principum. Pada waktu Thomas Aquinas kembali lagi ke Paris dan terlibat dalam kontroversi teologis dengan para pengikut Avveroes, Thomas Aquinas menulis De aeternitate munsi contramurmurantes, De unitate intellectus contra Averroistas, De Malo, De spiritualibus creaturis, De anima, De unione Verbi incarnati, De causis, dan Perihermeneias.

\section{B . Hakekat Kebahagiaan Menurut Thomas Aquinas}

Menurut Aquinas, Kebahagiaan tidak terletak pada barangbarang ataupun makanan, pakaian dan lain sebagainya, itu termasuk kedalam kebahagiaan yang tidak sempurna, seperti yang dapat dimiliki dalam kehidupan ini, barang-barang eksterior diperlukan, bukan sebagai esensi dari kebahagiaan, tetapi sebagai alat untuk kebahagiaan. Untuk kebutuhan manusia dalam kehidupan ini adalah kebutuhan tubuh, untuk latihan sebagai baik kontemplatif, sebagai kebajikan aktif. Kebahagiaan dikatakan sebagai kebaikan manusia yang berdaulat, karena itu adalah pencapaian atau kenikmatan dari yang berdaulat baik. ${ }^{17}$

Bahwa kebahagiaan yang hakiki itu tidak hanya didasarkan pada sesuatu yang dirasakan tubuh, karena itu belum cukup.

\section{Kebahagiaan Sebagai Tujuan Manusia}

Dari penjelasan di atas, disebutkan bahwa tindakan manusia itu mengarah ke obyek sebagai tujuannya. Tindakan kehendak itu mengarah ketujuan tersebut, karena dilihatnya sebagai yang memperlihatkan kebaikan, sementara hasrat manusia, memang mengarah kepada kebaikan untuk memperoleh kepuasan. Namun kenyataannya manusia tidak pernah akan memperoleh kepuasan yang sepenuhnya di dalam kehidupan di dunia ini. Sebagaimana akal budi terarah pada realitas tak terbatas, begitu pula kehendak manusia baru memperoleh kepuasan penuh pada kebaikan universal, nilai yang tertinggi sebagai tujuan yang terakhir. Apapun yang diciptakan di dunia ini terbatas, sehingga jelas tidak akan memberikan pemenuhan padaketakterbatasan kehendak manusia, 
dan tidak mungkin menjadi tujuan terakhir yang sebenarnya bagi manusia, yang memiliki keterarahan pada realitas yang tak terbatas. ${ }^{18}$

\section{Usaha memperoleh Kebahagiaan}

Setelah diketahui bahwa sumber kebahagiaan manusia adalah sang Ilahi, maka selanjutnya saya akan mengurai usaha memperoleh kebahagiaan menurut Thomas Aquinas. Aquinas mengatakan, manusia wajib untuk melakukan yang baik dan menghindari yang buruk. Selain yang baik itu sesuai dengan bagaimana kita berusaha untuk mencapai tujuan terakhir sudah jelas, yaitu melakukan yang baik dan menghindari yang buruk. Selain akal budi dapat memahami tentang yang baik yang buruk, manusia juga diarahkan oleh hati nuraninya untuk melakukan yang baik. Maka yang mejadi masalah berikutnya adalah bagaimana langkahnya agar kita tetap teguh melakukan yang baik dalam kehidupan ini. ${ }^{19}$

Menurut Aquinas, kemantapan untuk tetap melakukan yang baik dan menolak yang jahat disebut keutamaan ( virtus ). Keutamaan merupakan sikap hati yang sudah mantap, yang seakan-akan dapat diandalkan. Sikap atau kebiasaan hati itu terbentuk karena tindakantindakan yang biasa dilakukan. Misalnya, semakin manusia membiasakan diri bertindak dengan jujur, maka semakin gampang manusia untuk bertindak dengan jujur, semakin menjadi jujur, dengan demikian keutamaan kejujuran terbentuk dalam diri manusia. Adanya suatu keutamaan berarti bahwa orang yang bersangkutan telah memiliki arah dan kecenderungan tertentu dalam hidupnya. Arah tersebut, tentu saja mempermudah dan memperlancar setiap pengambilan sikap baru ke arah itu. Semakin tegas manusia mengambil sikap-sikap baik, maka semakin mudah manusia mengambil sikap-sikap baik selanjutnya. ${ }^{20}$

\section{F. PEMIKIRAN HAMKA TENTANG KEBAHAGIAAN}

\section{A. Biografi Hamka}

\section{Riwayat Hidup}

Nama lengkap beliau adalah Abdul Malik bin Abdul Karim Amrullah $^{29}$ beliau dilahirkan di sungai Batang Maninjau ( Sumatera Barat ) pada 17 Februari 1908 ( 14 Muharram1326 H ). Menurut silsilah, Hamka adalah anak tertua dari empat bersaudara kandung dari beberapa saudara tiri yang lain. ${ }^{21}$

\section{Latar Belakang Intelektualnya}


Dalam usia 6 tahun (1914) dia dibawa ayahnya ke Padang Panjang. Sewaktu berusia 7 tahun dimasukkan ke sekolah desa dan malamnya belajar mengaji Al- Qur'an dengan ayahnya sendiri sehingga khatam. Dari tahun 1916 sampai tahun 1923, dia telah belajar agama pada sekolah-sekolah " Diniyah School" dan Sumatera Thawalib" di Padang Panjang dan di Parabek. Gurugurunya waktu itu Syeikh Ibrahim Musa Parabek, Engku Mudo Abdul Hamid, dan Zainuddin Labay, Padang Panjang waktu itu ramai dengan penuntut ilmu agama Islam, di bawah pimpinan ayahnya. ${ }^{22}$

Ayahnya ulama terkenal, DR. Haji Abdul Karim Amrullah alias Haji Rasul, pembawa paham-paham pembaharuan Islam di Minangkabau. Ibunya bernama Siti Shafiyah Tanjung binti Haji Zakaria yang mempunyai gelar Bagindo Nan Batuah. Dikala mudanya terkenal sebagai guru tari, nyanyian dan pencak silat. ${ }^{23}$

\section{Karya- Karya Hamka}

Pada tahun 1928 keluarlah buku romannya yang pertama dalam Bahasa Minangkabau berjudul, Si Sabariyah. Waktu itu pula dia memimpin majalah Kemauan Zaman yang terbit hanya beberapa nomor. Pada tahun 1929 keluarlah buku-bukunya, Agama dan Perempuan, Pembela Islam, Adat Minangkabau dan Agama Islam (buku ini disita polisi), Kepentingan Tabhlig, Ayat-ayat Mi'raj, dan lain-lain. Pada tahun 1930 mulailah dia mengarang dalam surat kabar, Pembela Islam di Bandung, dan mulai berkenalan dengan M. Natsir, A, Hassan, dan lain-lain. Ketika dia pindah mengajar ke Makassar diterbitkannya majalah alMahdi. $^{24}$

Pada tahun 1930 mulailah dia mengarang dalam surat kabar, Pembela Islam di Bandung, dan mulai berkenalan dengan M. Natsir, A, Hassan, dan lain-lain. Ketika dia pindah mengajar ke Makassar diterbitkannya majalah al-Mahdi.

\section{B. Hakikat Bahagia Menurut Hamka}

Dalam membahas mengenai kebahagiaan, Hamka menceritakan sebuah alkisah, tiga orang berkawan berjalan di sebuah kampung yang ramai, dimana berdiri rumah-rumah yang indah tempat tinggal orang kaya, tuan-tuan, dan orang-orang yang bergaji besar. Ketika itu hari telah petang, matahari telah condong ke barat, di antara pergelutan siang dan malam itu, beberapa orang duduk di muka pekarangan rumahnya bersama anak dan istrinya, sambil membaca surat kabar yang terbit petang sambil istirahat selepas pulang dari pekerjaan. Di 
atas meja terletak beberapa mangkuk teh. Si ibu sedang menyulam, anak-anak sedang bermain kejar-kejaran di hamparan rumput halaman rumah yang hijau.

Seorang di antara dari ketiga yang bertamasya itu, demi mendengarkan perkataan kawannya itu menjawab 'ah ' jangan engkau terpercaya dari kulit lahir, karena dunia ini hanya komedi. Boleh jadi dibalik keindahan perkakas, dibalik senyuman dan tertawa itu ada beberapa kepahitan yang mereka sembunyikan. Yang tidak diketahui oleh banyak orang lain. Banyak orang yang tertawa sedangkan hatinya luka parah. Banyak orang yang tertipu dibalik melihat cahaya panas di waktu terik di tanah lapang luas, disangkanya cahaya itu air, bila sampai dia ke sana hanya pasir belaka. Banyak sekali yang rahmat dipandang lahir, tetapi pada batinnya laknat. ${ }^{25}$ Yang menjadi pertanyaan adalah apakah arti sebuah kebahagiaan, Dan dimanakah kebahagiaan itu berada?

\section{Usaha Memperoleh Kebahagiaan}

Di bawah ini, saya akan mengulas pemikiran Hamka, tentang empat keutamaan yang di perlukan untuk mencapai suatu kebahagiaan yaitu; agama, keutamaan otak dan budi, kesehatan jiwa dan badan, harta benda yang cukup.

\section{Agama}

Menurut Hamka, manusia yang bahagia adalah manusia yang dekat dengan Allah Swt. Dan di dalam agama manusia memiliki aturan dan pedoman untuk mendekat diri dengan Allah Swt. Hamka mengatakan agama mengandung fungsi untuk merentangkan jalan untuk mencapaisuatu kebahagiaan. ${ }^{26}$

\section{Keutamaan Otak dan Budi}

Hamka mengatakan dengan agama, iman, Islam dan I'tik $\bar{\alpha} d$, sudah dapat mencapai kebahagiaan batin dan perhubungan yang baik dengan Allah. Tapi diperlukan keutamaan otak dan budi untuk memperoleh suatu kebahagiaan. Hamka mengatakan, Manusia yang bahagia adalah yang memiliki keutamaan otak dan budi sehingga ia dapat semakin dekat dengan sumber kebahagiaan yaitu Allah Swt. Dengan keutamaan otak, seseorang akan mampu berpikir dengan akalnya tentang hakikat segala perkara, dapat membedakan jalan kebahagiaan dan jalan kesengsaraan atau jalan yang hina, tahu akan kesalahan dan menjauhinya. Semuanya didapat dengan otak yang cerdas, bukan karena ikut-ikutan. 


\section{Kesehatan Tubuh dan Jiwa}

Menurut Hamka, kesehatan jiwa dan badan sangat diperlukan untuk memperoleh suatu kebahagiaan, kalau jiwa sehat, dengan sendirinya memancarlah bayangan kesehatan itu pada mata, dari sana memancar cahaya yang gemilang, timbul dari sukma yang tiada sakit. Demikian juga kesehatan badan, dapat membukakan pikiran, mencerdaskan akal, menyebabkan juga kebersihan pada jiwa. Kalau jiwa sakit misalnya ditimpa penyakit marah, penyakit duka, penyakit kesal, kemudian dia membayang kepada badan kasar, tiba di mata merah, tiba di tubuh gemetar. ${ }^{27}$

\section{Harta Benda yang Cukup}

Hamka mengatakan bahwasanya orang bahagia itu bukanlah terletak kepada banyak kekayaan atau harta benda yang dimilikinya, karena sebaik-baiknya harta adalah hanya seperlu kebutuhan manusia saja, Hamka mengatakan orang kaya ialah orang yang sedikit keperluannya, jadi jangka naik turun kekayaan dan kemiskinan, ialah hajat dan keperluannya. Siapa yang paling Sedikit keperluannya, itulah orang yang paling kaya.

Siapa yang paling banyak keperluannya itulah orang miskin. Sebab itu orang yang paling kaya hanya seorang saja yaitu Allah. Sebab dia tidak berkehendak keperluan atau hajat. ${ }^{28}$

\section{Analisis Pemikiran Mengenai Kebahagiaan Thomas Aquinas dan Hamka}

Dalam bab ini, saya ingin menganalisis pemikiran kebahagiaan dari kedua tokoh filsuf yaitu, Thomas Aquinas dan Hamka, tapi dalam menganalisis pemikiran kedua tokoh ini, dimulai dari sejarah kehidupannya. Baru kemudian masuk pada pembahasan tentang makna kebahagiaan dan jalan mencapai suatu kebahagiaan. Masing- masing filsuf mempunyai konsep tersendiri, yang memungkinkan ada suatu persamaan dan perbedaan dalam pandangan kebahagiaan.Seperti yang dideskripsikan sebelumnya bahwa, Thomas Aquinas dan Hamka merupakan seorang, yang berpengaruh pemikirannya terhadap umat dalam agama yang mereka anut. Keduanya memiliki latar belakang dan pendekatan yang berbeda dalam pemikiran kebahagiaan.

Aquinas pada masa kecilnya sudah dibesarkan pada lingkungan gereja, Pada usia lima tahun, Aquinas diserahkan oleh orang tuanya ke Biara Benediktin di Monte Cassino dengan harapan bahwa kelak ia memilih hidup membiara. Memang sejak usia kecil, Aquinas sudah mengenyam pendidikan keagamaan, karena keinginan orang tuanya yang ingin menjadikan Aquinas seorang rahib. 
Semasa hidupnya, Aquinas mendapatkan pendidikan yang baik. Dan juga Ia menjadi murid Santo Albertus Agung. Dapat diperkirakan bahwa upaya Santo Albertus Agung untuk memanfaatkan filsafat Aristoteles dalam berteologi memberikan pengaruh awal bagi arah dan gaya berfikir Thomas Aquinas. Dan akhirnya nanti Thomas Aquinas terkenal sebagai teolog dan filsuf yang secara kreatif mampu menciptakan sintesis seluruh pemikiran Kristiani, dengan memanfaatkan sistem dan konsep-konsep filsafat Aristoteles.

Sedangkan Hamka, yang diharapkan oleh ayahnya menjadi seorang ulama, sejak kecil Hamka disibukkan dengan rutinitas sekolah dan mengaji pada ayahnya sampai khatam. Sikap otoriter sang ayah, membuat Hamka tidak menyenangi belajar, dan merasa bosan dengan pendidikan saat itu. Ia kemudian memilih belajar otodidak dengan membaca berbagai tulisan. Sampai akhirnya ia merantau ke Jawa dan memperoleh pembaharuan pemikiran yang dinamis dan modernis dari tokoh pembaharu Islam di Yogyakarta. Dan menurut Hamka kebebasan intektual berfikir merupakan pangkal kemajuan dunia.

Selanjutnya, pada bagian ini akan diurakan bagaimana persamaan pandangan, perbedaan pandangan dan jalan mencapai kebahagiaan yang dikonsep oleh Thomas Aquinas dan Hamka. Persamaan pemikiran Kebahagiaan Thomas Aquinas dan Hamka, sebagai berikut:

\section{Persamaan Dalam Pandangan Ilahi Sebagai Sumber Kebahagiaan}

Thomas Aquinas dan Hamka, memiliki pandangan yang sama mengenai sumber Kebahagiaan. Yang menekankan bahwa, kebahagiaan yang hakiki itu bersumber dari Tuhan. Aquinas, Kebahagiaan yang sebenarnya yang dirasakan oleh seseorang atau masyarakat tidaklah terletak pada benda, nilai atau materi tertentu, tetapi kebahagiaan itu terjadi ketika manusia memandang kemuliaan Allah. ${ }^{29}$

Begitu juga dengan Hamka, menurut Hamka, puncak kebahagiaan penghabisan ialah kenal dengan Allah, baik ma'rifat kepada-Nya, baik taat kepada-Nya, dan baik sabar atas ketentuannya. ${ }^{30}$ Dan Aquinas yakin bahwa, manusia bisa menikmati kebahagiaan yang bukan saja dirasakan untuk sementara tetapi lebih dari itu yakni kebahagiaan untuk selamanya dan tidak akan berkesudahan. Bagi Aquinas, semua itu akan terwujud jika manusia memandang Allah di saat ia telah beralih dari dunia ini yaitu setelah kematian. ${ }^{31}$

\section{Persamaan dalam usaha mencapai kebahagiaan.}


Thomas Aquinas dan Hamka, memiliki pandangan yang sama mengenai usaha mencapai Kebahagiaan. Yang menekankan bahwa, cara memperoleh kebahagiaan itu, harus didasari dengan berbuat kebajikan dan mejauhi perbuatan buruk. Aquinas mengatakan, manusia wajib untuk melakukan yang baik dan menghindari yang buruk. Selain yang baik itu sesuai dengan bagaimana kita berusaha untuk mencapai tujuan terakhir sudah jelas, yaitu melakukan yang baik dan menghindari yang buruk. Selain akal budi dapat memahami tentang yang baik yang buruk, manusia juga diarahkan oleh hati nuraninya untuk melakukan yang baik. ${ }^{32}$ Hamka mengatakan, seorang yang bahagia ialah yang memiliki keutamaan otak sehingga dapat berbuat kebaikan-kebaikan dalam kehidupan. ${ }^{33}$

\section{G. Kesimpulan}

Berdasarkan pada uraian tentang Konsep Kebahagiaan Pandangan Thomas Aquinas dan Hamka, Saya tidak ingin membandingkan untuk mencari mana yang lebih bagus dan mana yang lebih unggul dalam mengkonsep suatu kebahagiaan, tapi saya ingin mendeskripsikan pemikiran kedua tokoh mengenai pemikiran kebahagiaannya. Yaitu untuk menjawab pertanyaan dari rumusan masalah yang diatas.

Thomas Aquinas, memandang bahwa manusia tidak akan mendapatkan suatu kebahagiaan yang hakiki di dunia ini, karena dunia ini bersifat sementara, dan tempat yang tepat untuk mendapatkan suatu kebahagiaan yang hakiki adalah ketika manusia memandang Allah sebagai sumber kebahagiaan yang hakiki, didalam kitab Summa Theologicayang dikarang oleh Thomas Aquinas disana dijelaskan bahwa manusia akan mendapatkan kebahagiaan ketika manusia sudah bertemu dengan tuhan, yaitu ketika manusia sudah beralih dari alam dunia menuju alam baqa yaitu setelah manusia mati, jadi kehidupan ini jangan dijadikan sebagai tempat untuk memperoleh kebahagiaan yang hakiki, karena manusia kata Thomas Aquinas, tidak akan menemukannya. Dan jalan mencapai kebahagiaan, yaitu dengan mengikuti hukum kodrad yang sudah ditetapkan oleh Allah.

Maka dari itu manusia sudah barang tentu, jangan lah menjadikan kehidupan di dunia ini sebagai orientasi sebuah kebahagiaan yang sebenarnya, karena pada dasarnya kebahagiaan di dunia ini bersifat sementara. Akademisi yang agamis haruslah 
memiliki orientasi yang seiring dengan perkembangan zaman dan tetap berpedoman pada ajaran agama yang dianutnya, sebagaimana Hamka membumikan kembali tasauf pada masyarakat modern yang mulai pudar orientasi kerohaniannya. Dan Thomas Aquinas mendamaikan ajaran Filsafat dan Theologi dalam ajarannya. Akademisi yang agamis, yang mencintai hidup kerohanian harus mampu mengaplikasikan ilmu agamanya dalam segala aspek kehidupan, serta mengupayakan kesadaran umat untuk terus menggapai kemajuan dengan diiringi kesadaran hidup kerohanian agar kehidupan dapat terus maju tanpa harus kehilangan arah dan kendali. Dengan demikian dapat terwujud kebahagiaan bukan hanya bagi individu tetapi juga bagi masyarakat, bukan hanya di dunia, tetapi juga akhirat.

${ }^{1}$ Ibn Miskawayh, Menuju Kesempurnaan Ahklak, h. 64-63.

${ }^{2}$ Hamka, Tasauf Modern, ( Jakarta: Revublika, 2015)., h. 97.

${ }^{3}$ Hamka, Tasauf Modern, h. 97.

${ }^{4}$ Aquinas, Thomas, Summa Theologica, vol. 1 (edisi Inggris : Summa Theologica, Latin Text and English Translation, London New York, 1982: Burns And Oates, Granville Mansions, W.), h. 16

${ }^{5}$ Tim Penyusun Dar el-Machreq Sarl, Kamus al-Munjid ( Beirut: Dar el-Machreq Sarl, 2002), h.333.

${ }^{6}$ Mulyadhi Kartanegara, Pengantar Studi Islam, (Jakarta: UIN Press, 2010), h. 245.

${ }^{7}$ David Melling, Jejak langkah pemikiran Plato,( Jogjaakarta: Bentang Budaya, 2002), h. 1

${ }^{8}$ Mohammad Hatta, Alam Pikiran Yunani, (Jakarta: UI-Press, 1986) h. 115 .

${ }^{9}$ Frans Magnis Suseno. 13 Tokoh Etika, h. 27.

${ }^{10}$ Frans Magnis Suseno. 13 Tokoh Etika, h. 27.

${ }^{11}$ Asmoro Achmadi, Filsafat Umum, (Jakarta : PT. Raja Grafindo Persada, Ed. 1-cet. 14, 2003), h.55-56.

${ }^{12}$ Muhammad, Ustman Najati, Jiwa dalam Pandangan Para Filosof Muslim, (Bandung, Pustaka Hidayah, 2002), h. 85

13 Ensiklopedia Islam di Indonesia, Depag RI- Dirjend Pembinaan Kelembagaan Agama Islam Proyek Peningkatan Prasarana dan Sarana Perguruan Tinggi Agama/IAIN, Jakarta, 1992, h. 397.

${ }_{14}$ Waryono Abdul, Ghofur, Kristologi Islam Telaah Kritis Rad al Jamīl Karya Al- Ghāzālī, (Yogyakarta: Pustaka Pelajar 2006), h.25-26.

${ }^{15}$ Bertrand Russel. Sejarah Filsafat Barat, (Yogyakarta: Pustaka Pelajar 2002), h. 589. 2018.

${ }^{16}$ https: //idm. Wikipedia.org/wiki/Thomas- Aquinas, 28-Februari

${ }^{17}$ Aquinas, Thomas, Summa Theologica, Vol. I, h. 16.

${ }^{18}$ Hawasi, Thomas Aquinas: Menyelelaraskan Antara Iman dan Akal, (Jakarta: CV. Poliyama Widyapustaka, 2003.)

${ }^{19}$ Suseno, 13 Tokoh Etika, h. 87.

${ }^{20}$ Magnis.Suseno, Franz., Etika Dasar. Masalah-masalah Pokok Filsafat Moral, h. 86. 
${ }^{21}$ Musyafa, Haidar, HAMKA: Sebuah Novel Biografi, (Depok:

Penerbit Imania, 2016), h.23.

${ }^{22}$ Hamka, Tasawuf Modern, h.iii.

${ }^{23}$ Nasir Tamara, Hamka Dimata Hati Ummat,(Jakarta: Sinar Harapan, 1983), h. 51

${ }^{24}$ Hamka, Tasawuf Modern, h. iv

${ }^{25}$ Hamka, Tasawuf Modern, h.10

${ }^{26}$ Hamka, Tasawuf Modern, h. 57

${ }^{27}$ Hamka, Tasawuf Modern, h. 161

${ }^{28}$ Hamka, Tasawuf Modern, h. 229

${ }^{29}$ Harun Hadiwijono, Sari Sejarah Filsafat Barat I, h.12.

${ }^{30}$ Hamka, Tasawuf Modern, h. 27.

${ }^{31}$ K. Bertens, Ringkasan Sejarah Filsafat, h. 38

Moral, h. 85.

${ }^{32}$ Franz Magnis. Suseno Etika Dasar. Masalah-masalah Pokok Filsafat

${ }^{33}$ Hamka, Tasawuf Modern, h. 140 